\title{
WILD EDIBLE PLANTS IN GOURMET OFFER OF ECOTOURISM DESTINATIONS: CASE FROM BIOSPHERE RESERVE „GOLIJA-STUDENICA”
}

\author{
Milica Lukovićl, Danijela Pantović2, Mihailo Ćurčić3 \\ *Corresponding author E-mail: danijela.durkalic@kg.ac.rs
}

A R T I C L E I N F O
Original Article
Received: 01 November 2021
Accepted: 10 December 2021
doi:10.5937/ekoPolj2104061L
UDC 635.1/.8:[338.48-
6:641/642]

Keywords:

Golija Nature Park, wild edible plants, gourmet offer, ecotourism

JEL: Z32, Q20

\begin{abstract}
A B S T R A C T
Closely related to traditional agriculture consumption of wild plants it significantly contributes to the existence of the human species. The aim of this paper is to determine the value of ethnobotanical parameters (RFC, CI, CV) for the most important species that participate in creating the gastronomic offer of ecotourism destinations. The research was conducted in the area of the Biosphere Reserve (BR) "Golija-Studenica" as one of the attractive ecotourism destinations and sites with a high degree of biodiversity. As part of the site visit and research, during the period 20182020, the authors used the ethnobotanical questionnaire to quantify and determine the value of each individual species that plays a role in local traditional gastronomy, and today is part of the tourist offer. The results indicate the existence of a culture of using natural resources and a high degree of use of wild species in traditional recipes. Among the most exploited species, wild berries like blueberries stand out, but some species of mushrooms.
\end{abstract}

(C) 2021 EA. All rights reserved.

\section{Introduction}

It is generally known that there are wild plant species that grow spontaneously and affect the self-sufficiency of a population that is independent of human actions. The use and consumption of wild edible plants is a phenomenon that preceded agriculture and appeared in ancient times and cultures (Guil et al., 1997; Ojelel et al., 2019). Their collection, consumption and sale significantly contribute to human existence and affect food safety.

1 MilicaLuković,PhD,AssistantProfessor,University in Kragujevac, Faculty ofHotel Management and Tourism, Vojvodjanska 5A, 36210 Vrnjačka Banja, Serbia,Phone: +38162245630, E- mail: milica.petrovic@kg.ac.rs, ORCID ID ( https://orcid.org/0000-0002-7102-0178)

2 Danijela Pantović, PhD, Assisstant Professor, University in Kragujevac, Faculty of Hotel Management and Tourism, Vojvodjanska 5A, 36210 Vrnjačka Banja, Serbia, Phone +381645806599, E- mail: danijela.durkalic@kg.ac.rs, ORCID ID (https://orcid.org/0000-0001-8605-8614)

3 Mihailo Ćurčić, PhD, Assistant Professor | Research Associate, University of Defense, Social Sciences Department, Pavla Jurišića Šturma 33, 11000 Belgrade, Serbia, Phone: +381654009049, E- mail: curcicmihailo@gmail.com, ORCID ID (https://orcid.org/0000-0001-7674-0310) 
This study investigates the cultural significance in the diet of wild edible plants in the territory of the Republic of Serbia, with focus on BR ,Golija-Studenica”. Nature park Golija also includes the cultural wealth of the Studenica Monastery, which has been on the UNESCO World Heritage List since 1986 and is a very popular tourist attraction. Among all branches of industry, the tourism industry is considered the most sustainable in this region (Tomić \& Stojsavljević, 2013), especially because tourism has a Win-Win effect on one economy (Pantić \& Milojević, 2019).

As reported in research Burešova et al., (2020) gastronomy should be considered from the different points of view: historical and cultural aspect, creativity, available raw materials, methods and recipes especially aspects of local ingredients as basis of each diet, authenticity and unique taste. The same authors pointed out that gastronomy goes together with authentic environment shaped by climate and geographical features. The use of wild plants is an integral part of the traditional cultural system of the Golija area and the potential for creating economic value in agriculture, food production, human and animal nutrition. The potential of the gastronomic offer of BR "Golija-Studenica" as an ecotourism destination is processed by applying the Relative Frequency of Citation, Cultural significance index and Cultural importance index. The research showed that more than 26 species of wild edible plants were used in this area. The highest use value was found in berries, while most of the researched plants were used as tea, nectar or processed food. The most cited autochthonous wild plants are characterized by a high culture of consumption.

The hypothesis based on the facts that area of Golija mountain has significant natural potential (diversity of flora, climate, geographical features, ecotourism) as well as deep tradition, culture and knowledge of utilization of wild medicinal and aromatic species to present autochthonous products to tourists. This study intends to consider diversity of wild edible species in traditional gourmet offer with its use variety and cultural importance for this region. The novelty of this research refers to the first insight, on the small-scale, to highlight the most used species in food recipes, offered to the broader public, rather than its medicinal purpose as it was presented in previous studies.

\section{Literature review}

Edible wildlife products include a rich variety of plant forms and ethnobotanical characteristics ranging from grasses, shrubs and trees to mushrooms, algae and lichens. There are wild plants and other living organisms that are involved in the culture of human nutrition.

Wild plant species represent the unique importance of the biosphere that play a key role in cultural nutrition, providing direct and indirect resources for human consumption (Vinceti et al., 2013). Several authors, such as Powell et al., (2014) and Svanberg (2012), pointed out that wild food plays a significant role in the food system, especially when food insecurity is greatest, especially during dry or wet seasons. 
The authors of Carvalho \& Barata (2017) emphasized that wild edible plants especially serve as wild food for commercial and recreational purposes. In addition, this author emphasized the importance of wild plants for the sustainability of many rural areas. In addition, there are increasing examples of the availability of local wild herbs in local food markets. Pardo-De-Santayana et al., (2005) especially pointed out that when consuming wild edible plants in human nutrition, it is necessary to take into account social, economic and cultural factors. Based on these factors, traditional wild food was obtained, which represents an important segment in human nutrition. In addition to the fact that locally harvested wild edible plants participate in the human food chain, it also provides cash income for the indigenous population and plays a major role in ensuring global food security (Ju et al., 2013).

Blanco-Salas et al., (2019) concluded that wild plants have a high positive impact on sustainable rural development. Namely, according to the research of these authors, 145 species of wild plants on the Iberian Peninsula are useful for tourism and guiding consumers towards a high food culture, new gastronomy and environmentally friendly ways of food preparation.

There is a noticeable increase in the use of wild plants in protected areas that have the character of tourist hotspots. For example, several studies of the behavior and attitudes of tourists towards eating wild edible plants in these and similar areas have been conducted. The study by Wu et al., (2018) presents the results of a study conducted in China to examine the link between the consumption of wild edible plants and the tourist experience. According to the results, there is a great demand for these plants by tourists and locals due to tradition and the desire for green food. In addition, respondents perceive a low level of environmental responsibility despite the expressed environmental awareness. Similarly, Fuste-Forne (2019) used a case study to investigate the use of wild plants in forested parts of northeastern Spain. He established the deep role of this type of food in the culture and identity of local communities and the strong seasonal feature of tourist activities that has a direct impact on sustainable planning of forest capacities and tourism in rural areas.

When it comes to the natural resources of Golija, it should be noted that this area is a large source of drinking water, which has a dense network of about 500 springs, of which 250 are of good yield (Urošev, 2007). According to Grujičić-Tešić (2016), Golija has the densest watercourse network in Serbia of 2,100 m/ km2, which is on average three times more than in other parts of Serbia. This network consists of 15 smaller and larger rivers, so it can be said that Golija is a large hydrographic hub of western Serbia.

Due to special values, a part of the Nature Park was inscribed on the list of MAB (Man and Biosphere) by the decision of the UNESCO commission in October 2001, under the name "Golija - Studenica" and allocated as a Biosphere Reserve (53,804 ha). It is the first proclaimed Biosphere Reserve in the Republic of Serbia (there are 727 of them in the world, according to UNESCO MaB program). The reserve includes the largest part of the Nature Park "Golija", its most important landscapes and landscape values, 
natural rarities, together with the protected surroundings of the Studenica monastery. On the other hand, the richness of the Raška region in plant and animal species is a major tourist and ecological potential (Pavlović \& Golić, 2011).

Authors Freytag \& Vietze (2010) found a strong positive impact of biodiversity on the creation of a comparative advantage in tourism in poor and underdeveloped countries, which is more pronounced than in OECD countries. Here, the potential of sustainable tourism is seen in the absolute income from tourism per capita. Their creation is positively affected by the richness of biodiversity, while the negative impact lies in the eventual loss of the same.

Shaheen et al., (2017) used the significance of the cultural index (CSI) as a tool in their research, with the help of which they calculated the value of use (UV), which is a growing trend in quantitative research in this area in recent years. Also, in that sense, the relative frequency index (RFC) was used, which represents the result obtained by dividing the number of respondents who used a specific type with the total number of respondents. Similar to previous research, Ojelel et al., (2019) used the RFC index for each plant species separately as the ratio of subjects who used a particular species to the total number of subjects. By further descriptive statistical analyzes, the obtained values of these parameters were included in order to present and discuss the overall results. On the other hand, CSI can be used in various aspects of socio-cultural research, for example, Sutrisno et al., (2020) examined the preservation of ritual plants in the East Aceh region of Indonesia. The questionnaires included plant species, folk names, use and ritual tradition of this people. These sources were used as a methodological framework for this research.

\section{Material and methodology}

\section{Study area}

Mountain Golija belongs to the Dinaric mountain ark and as a part of Stari VlahRaška Mountain Range, it rises from the valley of the rivers Studenica, Brvenica and Moravica. Geographically Golija is located in south-west Serbia (43 $17^{\prime} 24^{\prime \prime} \mathrm{N}$; $20^{\circ} 19^{\prime}$ $19^{\prime \prime} \mathrm{E}$ ), following west-east direction for about $32 \mathrm{~km}$ in the shape of Latin letter " $\mathrm{S}$ ". Golija with surrounding mountains nestled in the vicinity of touristic centers of southwest and western Serbia (Novi Pazar-32km, Ivanjica- 40km, Raška-43km, Kraljevo$66 \mathrm{~km})$. According to exceptional natural values, the area of Mount Golija with associated mountains was proclaimed as a Nature Park "Golija" in 2002, as well as the Biosphere Reserve "Golija-Studenica", in the same year. This area comprises of coniferous, mixed coniferous-deciduous forests, pastures and meadows, but also of several water sources, streams and natural peat lakes. It is known that Golija possesses an imposing number of medicinal, aromatic and wild edible plants with a long historical tradition in use. In recent times this area becomes recognized as a favorable nature-based tourism destination with plenty of ecosystem services that the nature of Golija should offer. Besides outdoor activities, special attention is paid to local plant-based products and culinary specialties. 


\section{Data collection}

Data was collected between 2018 and 2020 at the affirmed touristic sites of Golija Mountain. For this purpose were selected 2 villages (Rudno and Bzovik) with hamlets, at the territory of Rudno plateau (Radočelo mountain) within the boundaries of Biosphere Reserve, as well as the wider territory of villages Devići and Dajići on Golija mountain. Standard semi structured ethnobotanical questioner conducted on 54 respondents, mostly experienced elderly women and holders of touristic objects (ethnolodge, ethno-apartments, and restaurants). The respondents were chosen "from door to door" with free will to be part of the survey. The ethnobotanical questioner composed of four parts: 1. Socio-demographic characteristics of respondents, 1 . Wild edible plant species, 2. Plant utilization, and 3. Final plant-based product in gastronomic offer. According to the respondent's categorization of wild edible plant use in traditional cuisine, we formed 12 use categories: 1. Nectar (N), 2. Tea (T), 3. Processed food (PF), 4. Spices (S), 5. Rakia (R), 6. Liqueur (L), 7. Salads (S), 8. Jam (Jm), 9. Winer stores (WS), 10. Pies (P), 11. Cake (C) and 12. Bread/dough (B/D). Fieldwork includes as well as a collection of available plant material that was cited during the interviews. Plant species were determined using botanical literature (Josifović, ed. 1970-1978) and stored with vouchers in the herbarium of Gastronomic laboratory at the Faculty of Hotel management and tourism in Vrnjačka Banja.

Figure 1. Map of research area
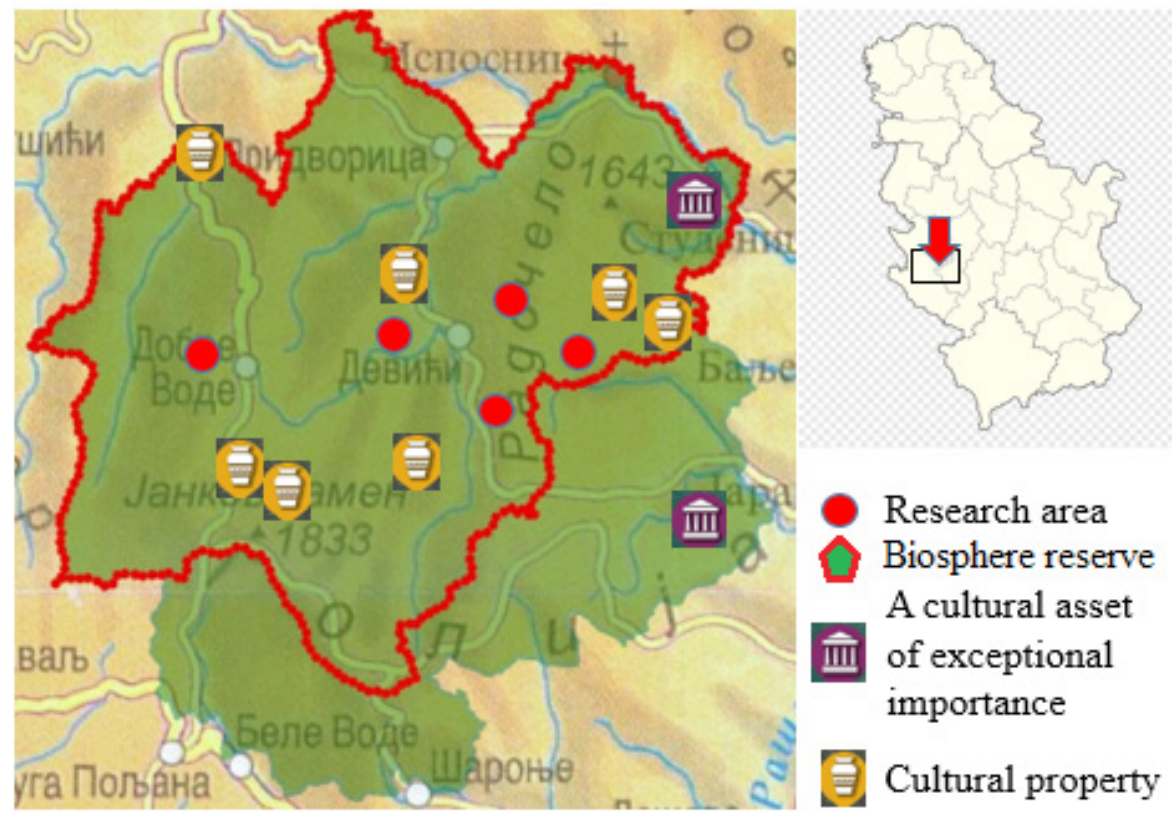

Source: Golija (Stari Vlah), available on: https://www.dinarskogorje.com/golija-stari-vlah. html, modified by authors 


\section{Data analysing}

Collected ethnobotanical data were classified and stored in excel databases for further analysis. Ethnobotanical questioner analyzed based on several parameters: 1. The number of Use Reports (UR), 2. Relative Frequency of Citation (RFC), Use value (UV), Informants' consensus factor (FIC), Cultural Value Index (CV), Cultural Importance Index (CI). The method of the ethnobotanical questioner is well confirmed and widely used in the science of ethnobiology, ethnobotany, ethnomedicine and ethnofood (e.g. Tardío et al., 2008; Abbasi et al., 2013; Shaheen et al., 2017; Ojelel et al., 2019, ect.)

The number of Use Reports (UR) represents a combination of three parameters: 1 . Respondents/informants " $i$ ", 2 . cite the use of the plant species " $s$ " in the determined use-category " $u$ " (3.). This parameter is important for the cultural importance of plants.

$$
\mathrm{UR}_{\mathrm{s}}=\sum_{u=u 1}^{u N C} \sum_{i=i 1}^{i N} U R \text { sui }
$$

-NS- species $(\mathrm{s} 1, \mathrm{~s} 2, \ldots, \mathrm{sNS})$ with a total number of use categories NC (u1, u2,..., uNC)

$-\mathrm{N}$ informants $(\mathrm{i} 1, \mathrm{i} 2, \ldots, \mathrm{iN})$

- $\mathrm{UR}_{\text {sui }}(0-1)$

The Relative Frequency of Citation (RFC) index represents the number how many times one species is mentioned by respondents. This parameter does not consider the use category of plants and is determined for each species as the ratio of respondents who cited a species to the total number of respondents.

$$
\mathrm{RFC}=\frac{\mathrm{FC}}{\mathrm{N}}
$$

Where $\mathrm{FC}$ is frequency of citation and $\mathrm{N}$ is total number of respondents.

The Use value (UV) demonstrates the relative importance of plants known locally.

$$
\left\{\mathrm{UV}=\sum \mathrm{U}_{\mathrm{i}} / \mathrm{N}\right\},
$$

where $\mathrm{U}_{\mathrm{i}}$ is the number of uses mentioned by each informant for a given species and $\mathrm{N}$ is the total number of informants (Appiah et al. 2017).

Cultural importance index (CI)- takes into account not only the spread of the use (Nnumber of informants) for each species but also the diversity of its uses. The theoretical maximum value of the index is the total number of different use-categories (NC) and defined by the following formula:

$$
C I_{S}=\sum_{U=U_{1}}^{U_{N C}} \sum_{i=i_{1}}^{i_{N}} U R_{u i} /_{N}
$$


Cultural Value Index (CV) designed by Reyes-García et al. (2006) represented with equation:

$$
C V_{s}=\left[N U_{s} /_{N C}\right] \times\left[F C_{s} /_{N}\right] \times\left[\sum_{U=U_{1}}^{U_{N C}} \sum_{i=i_{1}}^{i_{N}} U R_{u i} /_{N}\right]
$$

Where $\mathrm{NU}_{\mathrm{s}}$ is number of different uses reported for the each species; NC- total number of use-categories considered in the study

Pearson Correlation Coefficient was used as a good measure to quantify the nature of the linear relationship between variables numerically, in our case, to check the relationship between the ethnobotanical indices (UV and RFC, RFC and CI, etc.). It is the covariance ratio between two variables to their standard deviations (Appiah et al. 2017).

The final set of results presented tabular and using bar charts.

\section{Results and discussion}

\section{Socio-demografic characteristics of respondents}

The results report that $78 \%$ of all respondents were females, while $22 \%$ were males (Table 1). Traditionally and culturally females make the core of the population in terms of wild edible resources utilization or natural products produced in different countries, cultures, or ethnic groups around the globe what confirmed the number of studies (e.g. Yeşil et al., 2019). Voeks (2007) and Howard (2003) highlighted women as queens of plant resources, keepers of culture and tradition and they accent the role of females in natural products collection. The questioner included mostly the population of elders, especially experienced women $(68.2 \%)$, then middle age population $(24.07 \%)$ and only four young people what makes $(7.41 \%)$. Considering education level, no-educated or primary school level educated people (50\%) together with secondary school level $(42.59 \%)$ of total respondents, makeover the $92 \%$ interviewed population. In terms of economic status, $62.96 \%$ of respondents have an average income, less than average $18.52 \%$ same as over average income. A local economy based on agriculture primarily with $94.44 \%$, followed by wild natural products collection $38.9 \%$ and tourism with $27.8 \%$. Natural resources utilization reserved for the female population implicate that these activities bring a significant contribution to total household income. Following similar ethnobotanical studies (e.g. Reyes-García et al., 2008; Tardío et al., 2008; Shaheen et al., 2017, etc.) demographic parameters (gender and age) and socio-economic parameters (education level, economic status and economic activity) show that wild plant resources utilized in rural areas by elder people with traditional knowledge, by a lower level of education and with under average economic status. Wild edible plants represent the additional activity to agriculture and tourism. 
Table 1. Socio-demographic characteristic

\begin{tabular}{|l|l|c|c|}
\hline \multirow{4}{*}{ Variable } & \multicolumn{1}{|c|}{ Category } & $\begin{array}{c}\text { Number of } \\
\text { informants } \\
\text { N=54 }\end{array}$ & Percentages (\%) \\
\hline \multirow{4}{*}{ Gender } & Female & 42 & $78 \%$ \\
\hline \multirow{4}{*}{ Age } & Male & 12 & $22 \%$ \\
\hline \multirow{4}{*}{ Education } & $18-30$ & 4 & $7.41 \%$ \\
\cline { 2 - 4 } & $31-50$ & 13 & $24.07 \%$ \\
\cline { 2 - 4 } & $>50$ & 37 & $68.2 \%$ \\
\hline \multirow{4}{*}{ Economy } & No-education/Primary & 27 & $50 \%$ \\
\cline { 2 - 4 } & Secondary & 23 & $42.59 \%$ \\
\cline { 2 - 4 } & University & 4 & $7.41 \%$ \\
\hline \multirow{3}{*}{ Monthly income based on... } & $<$ of average & 10 & $18.52 \%$ \\
\cline { 2 - 4 } & average & 10 & $62.96 \%$ \\
\cline { 2 - 4 } & $>$ average & 51 & $18.52 \%$ \\
\cline { 2 - 4 } & Agriculture & 15 & $94.44 \%$ \\
\cline { 2 - 4 } & Tourism & 21 & $27.8 \%$ \\
\hline
\end{tabular}

Diversity and local impotrance of wild edible plants in the Biosphere Reserve „, GolijaStudenica"

According to ethnobotanical interweaves was mentioned 52 plant species which could be used as food. Of that total number of species, we extracted 26 with relative frequency citation (RFC) more than 0.3 (Table 2) to calculate other important parameters. Dataset is divided into 12 categories related to food. Results show that the highest cultural importance index (CI) have Vaccinium myrtilis (blueberry), Boletus spp. (porcini mushrooms), Mentha spp. (mint), Thymus serpyllus (thyme), Cantharesllus cibarius (chanterelle). All highlighted wild edible species has important economic value research areas and represent one of the significant sources of income what was the potential reason to be mentioned. In the list of the first ten also were mentioned traditional wild edible species such as Rubus fruticosus (blackberry), Fragaria vesca (wild strawberry), Urtica diorica (nettle), Lactarius piperatus (peppery milkcap), Origanum vulgare (oregano), also with high economic potential.

Pearson correlation was calculated for the important valiables, between RFC and UV, RFC and CI, UR and CI. All tested variables show positive correlation value. The results for UR-CI ( $\mathrm{r}=0.999)$ show almost maximal value of positive correlation, as well as for RFC-CI ( $\mathrm{r}=0.942)$ and RFC-UV $(\mathrm{r}=0.748)$. If number of respondents or citation for particular species increase, the use value or cultural index also increase. 
Table 2. Selected most frequently mentioned wild edible species by informants (UR- Use Reports, RFC - Relative frequency of citation, UV - the use-value, CV-Cultural Value Index, CI- Cultural importance index

\begin{tabular}{|c|c|c|c|c|c|c|c|c|c|c|c|}
\hline \multicolumn{2}{|r|}{ Species } & \multirow[t]{2}{*}{ UR } & \multirow[t]{2}{*}{ FC } & \multirow[t]{2}{*}{ RFC } & \multirow[t]{2}{*}{ NU } & \multirow[t]{2}{*}{$\mathbf{U V}$} & \multirow[t]{2}{*}{ CI } & \multirow[t]{2}{*}{ CV } & \multicolumn{3}{|c|}{ Ranking } \\
\hline Abb. & & & & & & & & & RFC & CI & $\mathrm{CV}$ \\
\hline $\mathrm{JC}$ & $\begin{array}{c}\text { Juniperus communis- } \\
\text { juniper }\end{array}$ & 42 & 32 & 0.59 & 7 & 1.61 & 0.78 & 0.27 & 14 & 11 & 7 \\
\hline $\mathrm{BP}$ & Betula pendula-birch & 24 & 18 & 0.33 & 2 & 0.46 & 0.44 & 0.02 & 26 & 24 & 26 \\
\hline UD & Urtica diorica-nettle & 48 & 32 & 0.59 & 5 & 1.70 & 0.89 & 0.22 & 13 & 8 & 10 \\
\hline $\mathrm{R}$ & Rumex spp.-greens & 40 & 33 & 0.61 & 4 & 0.94 & 0.74 & 0.15 & 12 & 14 & 14 \\
\hline $\mathrm{RF}$ & $\begin{array}{l}\text { Rubus fruticosus- } \\
\text { blackberry }\end{array}$ & 49 & 35 & 0.65 & 7 & 1.67 & 0.91 & 0.34 & 10 & 6 & 3 \\
\hline RI & Rubus ideus-raspberry & 37 & 28 & 0.52 & 5 & 1.52 & 0.69 & 0.15 & 17 & 16 & 13 \\
\hline FV & $\begin{array}{c}\text { Fragaria vesca-wild } \\
\text { strawberry }\end{array}$ & 48 & 37 & 0.69 & 5 & 1.80 & 0.89 & 0.25 & 9 & 7 & 9 \\
\hline $\mathrm{RC}$ & $\begin{array}{l}\text { Rosa canina- } \\
\text { pomegranate }\end{array}$ & 42 & 39 & 0.72 & 3 & 1.28 & 0.78 & 0.14 & 6 & 12 & 15 \\
\hline $\mathrm{CM}$ & $\begin{array}{c}\text { Crategus monogina- } \\
\text { haw }\end{array}$ & 27 & 20 & 0.37 & 2 & 0.39 & 0.50 & 0.03 & 24 & 22 & 23 \\
\hline PS & $\begin{array}{c}\text { Prunus spinosa- } \\
\text { blackthorn }\end{array}$ & 29 & 22 & 0.41 & 4 & 0.65 & 0.54 & 0.07 & 22 & 20 & 19 \\
\hline CMas & Cornus mas- cornel & 30 & 29 & 0.54 & 5 & 1.06 & 0.56 & 0.12 & 18 & 19 & 16 \\
\hline MO & $\begin{array}{l}\text { Melissa officinalis- } \\
\text { lemon grass }\end{array}$ & 35 & 31 & 0.57 & 4 & 0.93 & 0.65 & 0.12 & 16 & 18 & 17 \\
\hline $\mathrm{OV}$ & $\begin{array}{c}\text { Origanum vulgare- } \\
\text { oregano }\end{array}$ & 44 & 37 & 0.69 & 4 & 1.54 & 0.81 & 0.19 & 8 & 10 & 11 \\
\hline TS & $\begin{array}{c}\text { Thymus serpyllus- } \\
\text { Thyme }\end{array}$ & 54 & 40 & 0.74 & 4 & 1.52 & 1.00 & 0.25 & 5 & 4 & 8 \\
\hline $\mathrm{M}$ & Mentha sp.- Mint & 58 & 41 & 0.76 & 6 & 1.63 & 1.07 & 0.41 & 4 & 3 & 2 \\
\hline TO & $\begin{array}{l}\text { Taraxacum offinicale- } \\
\text { dendalion }\end{array}$ & 36 & 28 & 0.52 & 4 & 0.43 & 0.67 & 0.12 & 19 & 17 & 18 \\
\hline TM & $\begin{array}{l}\text { Teucrium montanum- } \\
\text { mountain germander }\end{array}$ & 24 & 23 & 0.43 & 3 & 0.69 & 0.44 & 0.05 & 21 & 25 & 20 \\
\hline $\mathrm{AU}$ & $\begin{array}{l}\text { Allium ursinum- wild } \\
\text { garlic }\end{array}$ & 41 & 34 & 0.63 & 7 & 1.50 & 0.76 & 0.28 & 11 & 13 & 6 \\
\hline VM & $\begin{array}{l}\text { Vaccinium myrtilis- } \\
\text { blueberry }\end{array}$ & 62 & 47 & 0.87 & 7 & 1.83 & 1.15 & 0.58 & 1 & 1 & 1 \\
\hline $\mathrm{ME}$ & $\begin{array}{l}\text { Morchella esculenta- } \\
\text { common morel }\end{array}$ & 25 & 19 & 0.35 & 3 & 0.44 & 0.46 & 0.04 & 25 & 23 & 24 \\
\hline $\mathrm{CC}$ & $\begin{array}{c}\text { Cantharellus cibarius- } \\
\text { chanterelles }\end{array}$ & 50 & 43 & 0.80 & 5 & 1.15 & 0.93 & 0.31 & 3 & 5 & 4 \\
\hline $\mathrm{AC}$ & $\begin{array}{l}\text { Agaricus campestris- } \\
\text { field mushroom }\end{array}$ & 28 & 25 & 0.46 & 2 & 0.48 & 0.52 & 0.04 & 20 & 21 & 22 \\
\hline LP & $\begin{array}{l}\text { Lactarius piperatus- } \\
\text { pepper milkcap }\end{array}$ & 47 & 38 & 0.70 & 1 & 0.70 & 0.87 & 0.05 & 7 & 9 & 21 \\
\hline LS & $\begin{array}{l}\text { Laetiporus sulphureus- } \\
\text { chicken-of-the-woods }\end{array}$ & 23 & 22 & 0.41 & 2 & 0.46 & 0.43 & 0.03 & 23 & 26 & 25 \\
\hline B & $\begin{array}{l}\text { Boletus spp.- porcini } \\
\text { mushrooms }\end{array}$ & 55 & 45 & 0.83 & 4 & 1.50 & 1.02 & 0.28 & 2 & 2 & 5 \\
\hline MP & $\begin{array}{l}\text { Macrolepiota procera- } \\
\text { parasol mushroom }\end{array}$ & 39 & 32 & 0.59 & 3 & 0.70 & 0.72 & 0.18 & 15 & 15 & 12 \\
\hline
\end{tabular}


Nature provides a broad specter of wild edible species for local people in terms of medicinal plants, applicative use in daily work, or supplementing nutrition (Delang, 2006). Western Balkan countries were subject of interest in different studies, especially were analyzed medicinal plants in traditional healing (e.g. Menković et al., 2011; Šavikin et al., 2013) but also wild edible plants (e.g. Pieroni \& Quave, 2014) where highlighted mountain plants such as Origanum vulgare, Rumex patientia, Urtica dioica and Vaccinium myrtillus as culturally, economic and gastronomy important species. Biosphere reserve "Golija-Studenica" represent one of the important biodiversity areas with more than 900 described plant species (including mushrooms) and with $20 \%$ of medicinal, aromatic or edible species (Gajić, 1984). Wild natural resources (both plants and mushrooms) play a historical role in the culture, medicine and nutrition of researched area. It is known that the first records of medicinal plant use were related to the monastery of Studenica (Dajić Stevanović et al., 2015). In the past and present, plant utilization finding a role in rituals (e.g. oak or spruce trees as "zapis"- sacred tree, Ocimum basilicum- basil) or in traditional medicine for humans and animals. The most believed species, beside garlic, is Teucrium montanum- mountain germander for which valid "rising from the dead" (Luković \& Nićiforović, 2021). In recent times many species become part of the local gastronomic offers in eco touristic destinations such as Golija mountain. Housewives in this region daily use about 20 plant/mushroom species as a spice, for bread, for cooked food. One of the most recognizable products is so-called "green bread" with about 10 aromatic plants.

According to a report on wild medicinal and aromatic plants for Balkan countries (Traffic, 2021), the most collected plant species in previous years include species from our results. That fact confirmed an economic value of these species and therefore its cultural importance and frequency of citation.

If consdidered biological categories of selected wild edible species, it is obvious that trees/ shrubs and wild berries together make $38.46 \%$ as leading natural products in gastronomic offer. Herbs make $34.6 \%$ of the total species, followed by mushrooms with $26.92 \%$ (Figure 2 ).

Figure 2. Grouped plant species in biological categories

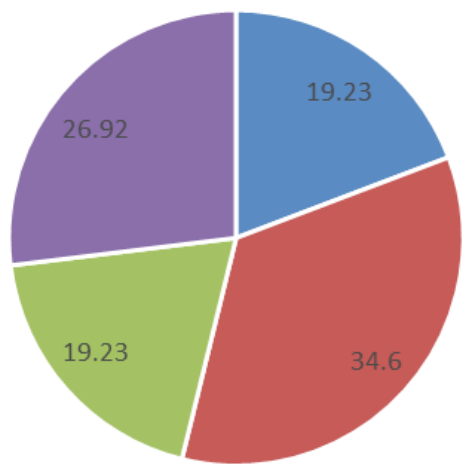

- Berries - Herbs $\mid$ Trees/shrubs - Mashrooms 
In to emphasize plants and their wide range of use we create a relationship between the number of specific categories (NU) in which wild edible species are mentioned and the number of respondents (FC) who cited particular species (Figure 3). This figure shows that only a small number of species has limited utilization in two categories. The number of wild edible plants used in different gastronomic products. The interesting fact is that wild berries found a way to be utilized in most of use-categories as nectar, jam, liqueur, cakes, as well as processed in cooked food. Mushroom have a high value of citation, but limited on processed food or specific products.

Figure 3. Relationship between the number of use-categories for each species (NU) and frequency of citation (FC).



Note: Abbreviations represent initials of species, see table 2.

\section{Wild edible plants in different gourmet categories}

Wild edible species were classified into 12 categories: 1. Nectar (N), 2. Tea (T), 3. Processed food (PF), 4. Spices (S), 5. Rakia (R), 6. Liqueur (L), 7. Salads (S), 8. Jam (Jm), 9. Winer stores (WS), 10. Pies (P), 11. Cake (C) and 12. Bread/dough (B/D). The table 3 presented the number of species-specific to each category and use reports for each species in each category. The highest value of use report recorded to the category of tea (T) with $20.03 \%$ of all analyzed use-categories. This result was followed by nectar (N)$17.71 \%$ and processed food (PF)- $14.36 \%$. In correlation to the high percentage of herbs participation (34.6\%), it is the logical to trace the number of medicinal plants (Thymus serpyllus, Mentha spp., Teucrium montanum, etc.). Although the category of bread/dough $(\mathrm{B} / \mathrm{D})$ is in the group of plants with the least percentages $(3.35 \%)$ the novelty and core of touristic attraction make spicy or green species. Also, one of the novelties is report on mushrooms utilization in the jam ( Jm) category. This kind of food is not recorded in previous studies and possibly represents the impact of modern gastronomy. 
Table 3. Number of use reports(UR) and species in use-categories

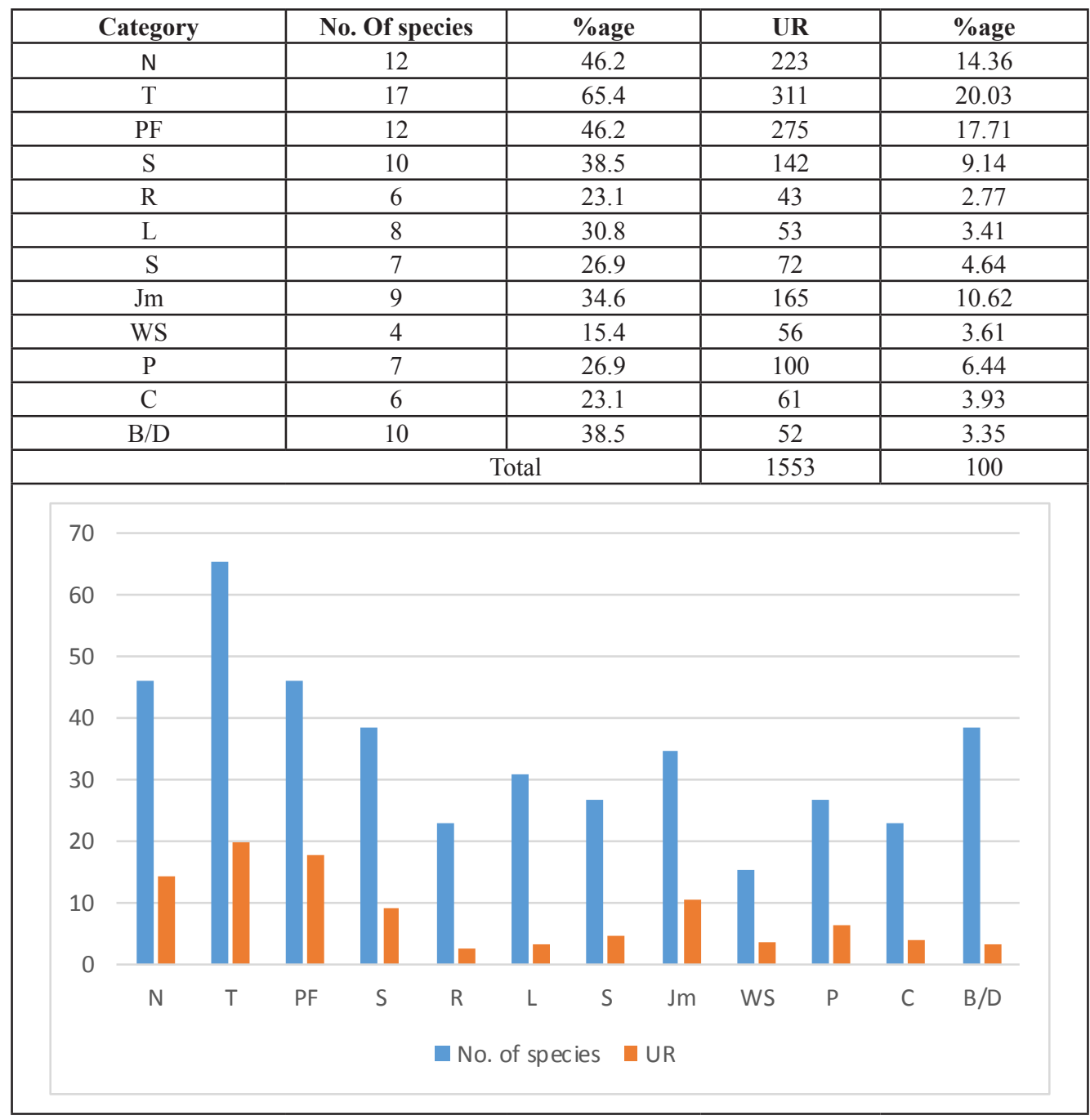

Note: 1. Nectar (N), 2. Tea (T), 3. Processed food (PF), 4. Spices (S), 5. Rakia (R), 6. Liqueur (L), 7. Salads (S), 8. Jam (Jm), 9. Winer stores (WS), 10. Pies (P), 11. Cake (C) and 12. Bread/ dough (B/D), Use report (UR)

Wild edible plants have long culture and tradition in Europe with several hundred species in use (Guarrera, 2003). South Europe with Balkan countries are recognized in numerous studies as an ethnobotanical worth region with exceptional plant diversity. Compare to other countries, Serbia has recorded 300 wild edible plants (Vračarić, 1977). Centers of plant diversity as well as centers of wild natural product use are mountain regions. There is a data according to Bonet \& Valles (2002) that region of Biosphere Reserve Montseney has 132 edible species and about $30 \%$ is in use, compared to our studies much less. Similar to our research, in Bosnia and Herzegovina (Jaman Redzic, 2006) show specter of wild edible 
plants use-categories from fresh salads, cooked food, beverages to ethnomedicinal purpose. They also emphasize the importance of Crataegus monogyna, Cornus mas, Urtica dioica, Melissa officinalis, Mentha sp., Taraxacum officinale in local nutrition. As reported in the study of wild edible fruits (Popović et al., 2020) berries are the most preferred group of wild edible plants for different use categories (fresh, medicinal purpose, jam, marmalade, alcoholic and non-alcoholic beverages) because of taste characteristics.

\section{Conclusion}

This study represents a report on ethnobotanical data in the gastronomic sector in selected ecotouristic destination BR "Golija-Studenica". The study analyzed several ethnobotanical parameters (RFC, CI, CV). According to results cultural importance and value show 26 wild edible species including wild berries, herbs and mushrooms. The highest value of diversity of utilization was found in berries, while most of cited plants were used as tea, nectar and processed food. Following all categories, Vaccinium myrtilis play a significant role in local gastronomy with the highest values of RFC, CI and CV. Respondents mostly cited plants with economic importance and which ones who represented potential addition to income, but also one who has potential to attract tourists. The limitation of this study was due to not considering the economic and practical value of wild edible plants. These ethnobotanical parameters are tasks for further researach.

\section{Acknowledgements}

This paper is a part of research project "Vrnjačka Banja villas as cultural heritage keepers", financed and supported by the Center for Scientific Research of Serbian Academy of Science and Arts and the University of Kragujevac and within the research program of the Faculty of Hotel Management and Tourism in Vrnjačka Banja, University of Kragujevac, which is funded by the Ministry of Education, Science and Technological Development of the Republic of Serbia.

\section{Conflict of interests}

The authors declare no conflict of interest.

\section{References}

1. Abbasi, A. M., Khan, M. A., Shah, M. H., Shah, M. M., Pervez, A., \& Ahmad, M. (2013). Ethnobotanical appraisal and cultural values of medicinally important wild edible vegetables of Lesser Himalayas-Pakistan. Journal of ethnobiology and ethnomedicine, 9(1), 66. doi: https://doi.org/10.1186/1746-4269-9-66

2. Appiah, K. S., Mardani, H. K., Osivand A., Kpabitey, S., Amoatey C. A., Oikawa, Y. and Fujii, Y. (2017). Exploring Alternative Use of Medicinal Plants for Sustainable Weed Management, Sustainability 9(8):1468.

3. Blanco-Salas, J., Gutiérrez-García, L., Labrador-Moreno, J., \& Ruiz-Téllez, T. (2019). Wild plants potentially used in human food in the Protected Area" Sierra Grande de Hornachos" of Extremadura (Spain). Sustainability, 11(2), 456. 
4. Bonet, M. A., and J. Valles (2002). Use non-crop food vascular plants in Montseny biosphere reserve (Catalonia, Iberian Peninsula). International Journal of Food Sciences and Nutrition, 53(3), 225-248.

5. Burešova, P., Mrkvova, K., \& Dudić, B. (2020). Changes in gastronomy. Hotel and Tourism Management, 8(1), 79-88. doi: https://doi.org/10.5937/menhottur2001079B

6. Carvalho, A. M., \& Barata, A. M. (2017). The consumption of wild edible plants. Wild plants, mushrooms and nuts: Functional food properties and applications, 159-198.

7. Dajić Stevanović, Z., Petrović, M., and Aćić, S. (2014). Ethnobotanical Knowledge and Traditional Use of Plants in Serbia in Relation to Sustainable Rural Development. In: Ethnobotany and Biocultural Diversities in the Balkans, A. Pieroni, C. L. Quave (eds.), Springer Science+Business Media New York, 229-252.

8. Delang, CO (2006). The role of wild food plants in poverty alleviation and biodiversity conservation in tropical countries. Progress in Development Studies. 6(4):275-286. doi:10.1191/1464993406ps143oa

9. Freytag, A., \& Vietze, C. (2013). Can nature promote development? The role of sustainable tourism for economic growth. Journal of Environmental Economics and Policy, 2(1), 16-44.

10. Fuste-Forne, F. (2019). Seasonality in food tourism: wild foods in peripheral areas. Tourism Geographies, doi: https://doi.org/10.1080/14616688.2018.1558453

11. Gajić, M., Savin, K. (1989). Flora i vegetacija Golije i Javora. [in English: Flora and vegetation of Golija and Javor] Beograd: Šumarski fakultet, Ivanjica: Šumarstvo „Golija“.

12. Golija (Stari Vlah), available on: https://www.dinarskogorje.com/golija-stari-vlah. html, accesss date: 8.11.2021.

13. Grujičić-Tešić, Lj. (2017). Geonasleđe Golije i Peštera: doktorska disertacija. [in English: Geoheritage of Golija and Pešter: doctoral dissertation]. Univerzitet u Beogradu, Rudarsko-geološki fakultet.

14. Guarrerra, M. (2003). Food medicine and minor nourishment in the folk traditions of Central Italy (Marche, Abruzzo, and Latium). Fitoterapia, 74(6), 515-544.

15. Guil, J. L., Rodríguez-Garcí, I., \& Torija, E. (1997). Nutritional and toxic factors in selected wild edible plants. Plant foods for human nutrition, 51(2), 99-107.

16. Howard, P.L. (2003). Women \& Plants: Gender Relations in Biodiversity Management and Conservation. Zed Books, London \& New York.

17. Jman Redzic, S. (2006). Wild Edible Plants and Their Traditional Use in the Human Nutrition in Bosnia-Herzegovina. Ecology of Food and Nutrition, 45(3), 189-232. doi: https://10.1080/03670240600648963

18. Jman Redzic, S. (2006). Wild Edible Plants and Their Traditional Use in the Human Nutrition in Bosnia-Herzegovina. Ecology of Food and Nutrition, 45(3), 189-232. doi:10.1080/03670240600648963

19. Josifović, M., ed. 1970-1977: Flora SR Srbije [in English: Flora of SR Serbia], I-IX. SANU. Beograd. 
20. Ju, Y., Zhuo, J., Liu, B., \& Long, C. (2013). Eating from the wild: diversity of wild edible plants used by Tibetans in Shangri-la region, Yunnan, China. Journal of Ethnobiology and Ethnomedicine, 9(1), 1-22. doi: https://doi.org/10.1186/17464269-9-28

21. Luković, M. \& Nićiforović, J. (2021). Increased demands for natural immuno-boosters in selected tourism areas. Tourism challenges aimed COVID-19, Tourism International Scientific Conference Vrnjačka Banja - TISC, 4-5 June, 2021, 6(1), 366-381.

22. Menković, N., Šavikin, K., Tasić, S., Zdunić, G., Stešević, D., Milosavljević, S. \& Vincek, D., (2011). Ethnobotanical study on traditional uses of wild medicinal plants in Prokletije Mountains Montenegro. Journal of Ethnopharmacology, 133, 97-107.

23. Ojelel, S., Mucunguzi, P., Katuura, E., Kakudidi, E. K., Namaganda, M., \& Kalema, J. (2019). Wild edible plants used by communities in and around selected forest reserves of Teso-Karamoja region, Uganda. Journal of ethnobiology and ethnomedicine, 15(1), 1-14. doi: https://doi.org/10.1186/s13002-018-0278-8

24. Pantić, N.., \& Milojević, I.. (2019). Investments and employment in tourism in the Republic of Serbia. Hotel and Tourism Management, 7(1), 95-104. https://doi. org/10.5937/menhottur1901095P

25. Pardo-De-Santayana, M., Tardío, J., \& Morales, R. (2005). The gathering and consumption of wild edible plants in the Campoo (Cantabria, Spain). International Journal of Food Sciences and Nutrition, 56(7), 529-542. Doi: https://doi. org/10.1080/09637480500490731

26. Pavlović, M. \& Golić, R. (2011). Tourism potentials of the Raška region and development of rural tourism. Glasnik Srpskog geografskog drustva, 91(3), 39-64. https://doi.org/10.2298/GSGD1103019J

27. Pieroni A. \& Quave C. (2014). Wild Food and Medicinal Plants Used in the Mountainous Albanian North, Northeast, and East: A Comparison. In: Pieroni A., Quave C. (eds) Ethnobotany and Biocultural Diversities in the Balkans. Springer, New York, NY. doi: https://doi.org/10.1007/978-1-4939-1492-0_10

28. Popović, Z., Matić, R., Stefanović, M., Vidaković, V., \& Bojović, S. (2020). Biodiversity of wild fruits with medicinal potential in Serbia. Biodiversity and Biomedicine, 161-188. doi: https://10.1016/b978-0-12-819541-3

29. Powell, B., Ouarghidi, A., Johns, T., Ibn Tattou, M., \& Eyzaguirre, P. (2014). Wild leafy vegetable use and knowledge across multiple sites in Morocco: a case study for transmission of local knowledge?. Journal of Ethnobiology and Ethnomedicine, 10(1), 1-11. doi: https://doi.org/10.1186/1746-4269-10-34

30. Reyes-García, V., Huanca, T., Vadez, V., Leonard, W., \& Wilkie, D. (2006). Cultural, practical, and economic value of wild plants: a quantitative study in the Bolivian Amazon. Economic botany, 60(1), 62-74.

31. Šavikin, K., Zdunic, G, Menkovic, N., Zivkovic, J., Ćujić, N., Tereščenko, M., \& Bigović, D. (2013). Ethnobotanical study on traditional use of medicinal plants in South-Western Serbia, Zlatibor district, Journal of Ethnopharmacology, 146 (3), 803-10. 
32. Shaheen, H., Qureshi, R., Qaseem, M. F., Amjad, M. S., \& Bruschi, P. (2017). The cultural importance of indices: A comparative analysis based on the useful wild plants of Noorpur Thal Punjab, Pakistan. European Journal of Integrative Medicine, 12, 27-34. doi: https://10.1016/j.eujim.2017.04.003

33. Sutrisno, I. H., Akob, B., Navia, Z. I., Nuraini and Suwardi, A. B. (2020). Documentation of ritual plants used among the Aceh tribe in Peureulak East Aceh District, Inodnesia. Biodiversitas, 21(11), 4990-4998. doi:https://doi.org/10.13057/ biodiv/d211102

34. Svanberg, I. (2012) The use of wild plants as food in pre-industrial Sweden. Acta Societatis Botanicorum Poloniae, 81(4), 317-328. DOI: https://doi.org/10.5586/ asbp. 2012.039

35. Tardío, J., \& Pardo-de-Santayana, M. (2008). Cultural Importance Indices: A Comparative Analysis Based on the Useful Wild Plants of Southern Cantabria (Northern Spain)1. Economic Botany, 62(1), 24-39. doi: https://10.1007/s12231007-9004-5

36. Tomić, N., \& Stojsavljević, R. (2013). Spatial Planning and Sustainable Tourism-A Case Study of Golija Mountain (Serbia). European Researcher, (12-2), 2918-2929. doi: https://doi.org/10.13187/issn.2219-8229

37. Traffic, Traditional and wild, available on: https://www.traffic.org/publications/ reports/traditional-and-wild-revitalising-traditions-of-sustainable-wild-plantharvesting-in-central-europe/, access date: 8.11.2021.

38. UNESCO-MaB, World network of Biosphere Reserves, available on: https:// en.unesco.org/biosphere/wnbr, access date: 13.11.2021.

39. Urošev, M. (2007). Sliv Golijske Moravice-hidrološka analiza. [in English: Golijska Moravica basin-hydrological analysis] Geografski institut" Jovan Cvijić" SANU.

40. Vinceti, B., Termote, C., Ickowitz, A., Powell, B., Kehlenbeck, K. \& Hunter, D. (2013) The contribution of forests and trees to sustainable diets. Sustainability 5, 4797-4824.

41. Voeks, R.A. (2007). Are women reservoirs of traditional plant knowledge? Gender, ethnobotany and globalization in northeast Brazil. Singapore Journal of Tropical Geography, 28(1), 7-20. doi: https://10.1111/j.1467-9493.2006.00

42. Vračarić, B. (ed.) (1977). Nutrition in nature. Military publishing institute and People's book. (in Serbian: Ishrana u prirodi. Vojnoizdavački zavod i Narodna knjiga), Beograd.

43. Wu, J., Hou, Y. and Wen, Y. (2018). Tourist behavior and conservation awareness on eating wild edible plants in mountainous protected areas: a case study in Northwest China. Journal of Sustainable Forestry, 37(5), 489-503. doi: https:// doi.org/10.1080/10549811.2018.1428901

44. Yeşil, Y., Çelik, M., \& Yılmaz, B. (2019). Wild edible plants in Yeşilli (MardinTurkey), a multicultural area. Journal of ethnobiology and ethnomedicine, 15(1), 1-19. doi: https://doi.org/10.1186/s13002-019-0327-y 